\title{
An Inductive-ROC Based Model for Determining Purchasing System Requirements
}

\author{
Tijen Över Özçelik ${ }^{1 *(D)}$, Orhan Torkul² \\ ${ }^{1,2}$ Sakarya University, Faculty of Engineering, Department of Industrial Engineering, Sakarya/Turkey \\ tover@sakarya.edu.tr, torkul@sakarya.edu.tr
}

\begin{abstract}
The success of system development studies depends on the completeness and accuracy of the requirements collected from system user and stakeholders. Mistakes and deficiencies in the requirements determination process lie in the failure of many system development studies. The dynamism and complexity of today's systems make the requirements determination process even more complicated, and the requirement determination phase, which is the primary stage of system development studies, gains excellent importance. Although there are many techniques, strategies, and models in the literature to improve the requirements Determination process, there are very few studies on their multiple-use, classification of needs, and their experimental realization in a real system. In this study, a system development study was carried out using the System Requirements Model (SRM), which has a flexible structure that allows the system needs to be determined with the use of multiple techniques, at the same time classifies the identified requirements, can decide on the determination levels, and allows the work to be stopped if a sufficient level of needs is determined The developed model consists of three stages: requirement identification, rulemaking/technical/needs matrix creation and classification of needs. In the needs determination process, collection, presentation, verification, and sort of needs. In the second stage of the model, an analogy was made, and the needs and techniques were grouped with the ROC algorithm, and the rule-based RULES-3 algorithm was used to universalize the model. In the third stage of the model, needs were determined based on technical/technical combinations.
\end{abstract}

Anahtar Kelimeler: Requirements Determination, Requirements Determination Techniques, Stoping Rules, Requirements Engineering, Rank Order Cluster, Inductive Learning, RULES-3.

\section{Satın Alma İhtiyaçlarını Belirlemede Endüktif-ROC Temelli Bir Model}

$\ddot{O} \mathbf{z}$

Sistem geliştirme çalışmalarının başarısı sistem kullanıcıları ve paylaşımcılarından toplanan ihtiyaçların tamlığı ve doğruluğuna bağlıdır. Birçok sistem geliştirme çalışmasının başarısızlığında da ihtiyaç belirleme sürecinde ki hatalar ve eksiklikler yatmaktadır. Günümüz sistemlerinin dinamikliği ve karmaşıklı̆g ihtiyaç belirleme sürecini daha da güçleştirmekte ve sistem geliştirme çalışmalarının öncelikli aşaması olan ihtiyaç belirleme aşaması büyük önem kazanmaktadır. İhtiyaç belirleme sürecinin iyileştirilmesi amacı ile literatürde birçok teknik, strateji ve model bulunmasına karşın bunların çoklu olarak kullanımı, ihtiyaçların sınıflandırılması ve gerçek bir sistemde deneysel olarak gerçekleştirilmesine yönelik çok az sayıda çalışma bulunmaktadır. Bu çalışmada çoklu teknik kullanımı ile sistem ihtiyaçlarının belirlenmesine olanak sağlayan, aynı zamanda belirlenen ihtiyaçları sınıflayan, belirlenme seviyelerine karar verebilen ve yeterli seviyede ihtiyaç belirlenmesi durumunda çalışmanın durdurulmasına izin veren esnek bir yapıya sahip Sistem İhtiyaçları Modeli (SIM) kullanılarak bir sistem geliştirme çalışması gerçekleştirilmiştir. Geliştirilen model ihtiyaç belirleme, kural çıkarma/teknik/ihtiyaç matrisi oluşturma ve ihtiyaçların sınıflanması şeklinde üç aşamadan oluşmaktadır. İhtiyaç belirleme sürecinde; ihtiyaçların toplanması, sunulması, doğrulanması ve sınıflanması gerçekleştirilmiştir. Modelin ikinci aşamasında bir analoji gerçekleştirilerek ROC algoritması ile ihtiyaç ve teknikler gruplanmış ve modelin evrenselleşmesi için kural tabanlı RULES3 algoritması kullanılmıştır. Modelin üçüncü aşamasında ise teknik/teknik kombinasyonları bazında ihtiyaçlar belirlenmiştir.

Anahtar Kelimeler: İhtiyaç Belirleme, İhtiyaç Belirleme Teknikleri, Durdurma Kuralları, İhtiyaç Mühendisliği, Derece Sıralama ve Kümeleme, Endüktif Öğrenme, RULES-3.

\footnotetext{
* Corresponding Author. 


\section{Introduction}

With the developments in technology, information systems have changed the processes of enterprises and have become the most important component of enterprises. In a world where data increases rapidly and information becomes more valuable than anything else, it is only possible for businesses to gain competitive advantage and maintain their existence if they have an effective information system (Laudon, 2014). Thanks to the reports produced by the information systems, the decision-makers (managers) can make decisions at both strategic, tactical, and operational levels, while the objectivity and accuracy of the decisions can increase. At the same time, thanks to these systems, productivity can be increased, and costs can be reduced, and superiority can be achieved against competitors thanks to new products, services, and processes. In this context, digitalization and information systems play a significant role for businesses (Cascio and Montealegre, 2016). The more necessary and important it is for businesses to be digitized and knowledge-based, the more complex and difficult it is to develop such systems. Because of rapidly changing, highly dynamic business environments, a large number of stakeholders and needs make it difficult to develop these systems. In the literature, it is stated that the stage with the highest effort and cost in system development projects is analysis, and it is argued that the problems and failures are caused by the need identification, which is the primary stage of the analysis process (Watson and Frolick, 1993; Davis, 1982; Byrd et al.,, 1992; Vessey and 1993; Wetherbe, 1991; Whitten and Bentley, 2007; Vessey and Conger, 1994). Needsbased problems point to the inadequacy of the developed system, thus rendering the effort and cost-ineffective (Alvarez, 2002; Sommerville at al., 1998; Guinan at al., 1998).

Requirements determination in the literature; is defined as collecting and modeling information for the functions required for the desired system by system developers/analysts (Sommerville at al., 1998). According to another definition, it is the form of understanding and solving the user requirements and problems for the desired system, collecting information for this purpose by system analysts, meeting the system and user requirements with a user-centered approach (Lazar at al., 2000). The concept of requirements engineering is also used in some studies to determine needs and focuses on the methods used in system development studies to extract and validate the set of needs (Hanish at al., 2001). According to the literature, there is a great deal of interest in the needs identification process and the problems experienced in this process.

In this study, the requirements determination process needs inference techniques and stopping rules based on the collected needs assessment are examined in detail. In order to improve the needs determination process, a flexible model was presented and applied to the determination of purchasing process needs. The model is a flexible model that can use the techniques defined in the literature together, thus determining the needs ultimately, classifying the identified needs and deciding to what extent they have been determined, and allowing the determination of needs to be stopped when necessary. The validity of the model was also tested with statistical methods.

\section{Literature Review}

Identifying requirements in information system development studies is an activity that requires a great deal of effort and is equally challenging. Identifying/identifying, and verifying needs are seen as the two most critical tasks in system development studies (Hanish at al., 2001). It is emphasized that the identification of the requirement is the phase of the system development process that should be best defined (Lazar at al., 2000; Davidson, 2002; Darke and Shanks, 1997; Browne and Pitts, 2004; Freeman, 2004) and it is one of the most challenging information system development activities (Watson and Frolick, 1993; Davis, 1982; Browne and Rogich, 2001; Janz, at al.). Studies on needs determination are in the literature; Identification of information needs, extraction of needs, needs Determination techniques, or needs engineering.

In the system development process, requirements extraction, analysis, validity, and management are intertwined. Extracting needs is also about discovering the needs of the stakeholders. It is basically based on collecting information about the existing system and the desired system. In this activity, it means performing the processes related to the needs repeatedly. The discovery of knowledge and requirements associated with this repetitive and other activity is also called inference. Each stage in this process requires preparation, practice, and analysis. In this sense, system developers and analysts should work on which inference technique should be selected in which process. For this purpose, it is necessary to understand the existing system, organizational structure and application area, and constraints, determine the needs and the characteristics of the current needs, analyze the Users and stakeholders, choose the techniques, tools, and approaches to be used in the needs process. Finally, the requirements should be determined to include all resources (Carrizo at al., 2014). For this reason, it is vital to determine the actual participants of the system and their needs. In addition, mutual interviews with the stakeholders, the experience of the analysts, and the methods and techniques they prefer are decisive in determining the highquality requirements related to the field and the system in the inference phase (Shams at al., 2019).

There is a direct relationship between the success of the developed systems and the complete and sufficient system requirements. In addition, the quality of the system requirements determination process is very much related to the communication and interaction 
among the users of the system, analysts, and stakeholders. Incompatibility and communication problems between these groups fail in system development studies (Freeman, 2004). Interviews with the users of the system and senior managers are generally very effective in determining the features of the desired system/reducing the needs. However, the Joint Application Development (JAD) technique is recommended when there are differences in knowledge and perspectives between the users of the system and the analysts (Duggan, 2003). Although it is emphasized in the literature that accurate and complete information needs play a vital role in the planning and implementation of business information systems, it is stated that it is often difficult to collect information needs wholly and accurately (Davis, 1982). This difficulty is due to three reasons;

$\checkmark$ Constraints on people such as problem solvers and information processors,

$\checkmark$ Diversity and complexity of IT needs,

$\checkmark$ It can be shown as the complexity of the interaction between the user and the analysts in defining the needs (Davis, 1982).

The best solution to overcome such problems is advocated for using several different methods and strategies (Hickey and Davis, 2004). Strategies for determining information needs; questioning, deriving from an existing information system, synthesizing the system's characteristics, and discovering from the experience of a developing system. While one of these strategies is determined as the primary strategy, the others should be preferred as supporting strategies. There are different methods and techniques for each strategy. For example, to query; questionnaires, for derivation from an existing information system; existing software, for synthesizing from the characteristics of the system used; process analysis is for discovering from the experience of a developing system; prototyping is recommended (Davis, 1982). Requirements inference techniques; It is highly related to the characteristics of people, processes, and projects. Each technique has different characteristics related to these application areas. For this purpose, an approach that allows the selection of requirements acquiring techniques to achieve the best result in the needs inference process is presented, and in the first stage of the approach, three dimensions as project, people, and process are defined. In the second stage; Three $\mathrm{P}$ matrices (3PM) were created, and the relationships between inference techniques and three dimensions were demonstrated. In the third and final stage, the generation of a criteria map for the selection of the inference technique is explained (Tiwari and Rathore, 2017).

System/software development studies are processes based on the solution of user needs and the satisfaction of sharing purposes. Some requirements may be intense, complex, and based on multidisciplinary needs. At the same time, the success of traditional acquiring methods in meeting the needs depends on the users. Because these methods mainly adopt a technical approach rather than a socio-technical point of view and focus on system constraints. Success in information system development depends on identifying the social, organizational, and technical characteristics of the system. At the same time, success in system development is a result based on the acceptability of the system by the users of the system. For this purpose, a socio-technical requirement acquiring process that enables the systematic determination of user needs has been proposed and demonstrated by an experimental study. In the study, the quality of the questions, the readability of the interviews, and the effect of the model on the success of the analyst in terms of socio-technical understanding of the field were evaluated (Wahbeh at al., 2019).

Requirements engineering and system development studies are about discovering the needs of users and stakeholders of the system. Although there are many techniques used by analysts for this purpose, one of the most frequently used is interviews (Bano at al., 2018). Interviews are particularly effective in extracting nonimplicit information. At the same time, the analysts' prior knowledge of the field affects the process positively and contributes to understanding the requirements and increasing communication. However, excessive content knowledge can sometimes lead to prejudices (Hadar at al., 2012). Another issue that has been studied related to the determination of needs is the stopping rules. Stopping rules are about when to stop the need inference and information Gathering process. For this purpose, a needs classification that can be used in information system development studies was carried out (Byrd et al.,, 1992), and this classification was later developed (Browne and Rogich, 2001). In another study, the need classes were organized at four levels; goal, process, task, and information-level needs. These requirements can be used in many other problem areas and in any system development work (Browne and Rogich, 2001; Browne and Pitts, 2004). Thanks to these requirements groups, the collected needs can be effectively measured in terms of quality and quantity (Browne and Pitts, 2004). The aim here is to classify the requirements using the identified needs and the analyst's experience. Requirement classes are used as stopping rules to terminate the Process (Pitts and Browne, 2004). The study, starting from the idea that the purpose of the analyst in a design process is to collect enough information, and this information should be measured; carried out a classification of needs. This classification template includes problem areas of assets believed to be critical to the successful design of information systems. This template is also used as stopping rules, thus preventing the extraction of missing or excess information (Browne and Pitts, 2004). A systematic mapping study carried out indicates that there are many studies with requirements acquiring techniques, but there are not many studies based on evaluating the performance of these techniques (Pitts and Browne, 2004). 
Improving the process of determining the requirements, in other words, it is said that not determining the needs more than or completely will lead to the development of more efficient and effective information systems in terms of gain, cost, and customer satisfaction, but it is not possible to eliminate the problems of determining the information needs suddenly and completely. This is a difficult process. Therefore, in order to improve the needs assessment process, it should be done step by step within the scope of a model by providing a better understanding of the stages of information collection, presentation, and validation. According to the needs, determination research results; The ability to overcome all problems, and the successful conclusion of system development studies depend on determining the set of needs in the most appropriate and complete way. For this reason, many scientists and researchers have carried out research on this subject and developed many techniques and tools for determining requirements. However, although there are many studies on requirements determination, requirements identification/development techniques, strategies, and requirement classification, application studies on comparison of requirements identification techniques and modeling the requirements identification process are very limited. Research on requirements assessment shows that there is a requirement for models for the comparison of needs assessment techniques and the integrated use of these techniques and that there is a gap in this area. Scientists generally argue that the use of multiple techniques is appropriate for their needs, but they do not provide a model for how to use multiple techniques. As a result, there is a need for a model and applications that can overcome the problems that may arise from incomplete needs collection in the needs determination process, use more than one technique together, and decide on the adequacy by measuring the collected needs. For this purpose, a flexible model was presented in the study and applied in determining the purchasing process needs. The model is a flexible model that can use technical combinations together, thus improving the needs determination process, classifying the determined needs with the stopping rules, and allowing the need determination to be stopped when necessary.

\subsection{System Requirements Model (SRM)}

In this section, a flexible model developed considering the problems that may be encountered in the needs identification process is presented. This model has three stages, and these stages are; needs determination process, rulemaking/technical/needs matrix creation, and the last step is the classification of requirements. The model is shown schematically in Figure 1. The requirements identification process, which is the first stage of the model, consists of four sub-stages. These; gathering the requirements, presenting the gathered requirements, verifying the requirements presented by the experts in the field, and classifying the requirements. At the stage of meeting the requirements, questionnaires, observation, interview, software review, literature review, and document analysis methods were used.

In order to present the needs, flowchart, associative information map, decision map, scenario, and similarity diagram techniques were used. After the needs presented with the techniques defined in the model are verified by the field experts, through a template created from the literature; It is classified into four levels as goal, process, task, and informatics. Thanks to this classification, a template was tested for the adequacy of the identified requirements and contributed to the verification of the identified requirements. In the second stage of the model; By making an analogy, the ROC algorithm, which is widely used in the grouping of parts and machines in manufacturing, was used to group the requirements and techniques. In order to universalize the model and increase its usability, an artificial intelligence-based RULES-3 algorithm was used.

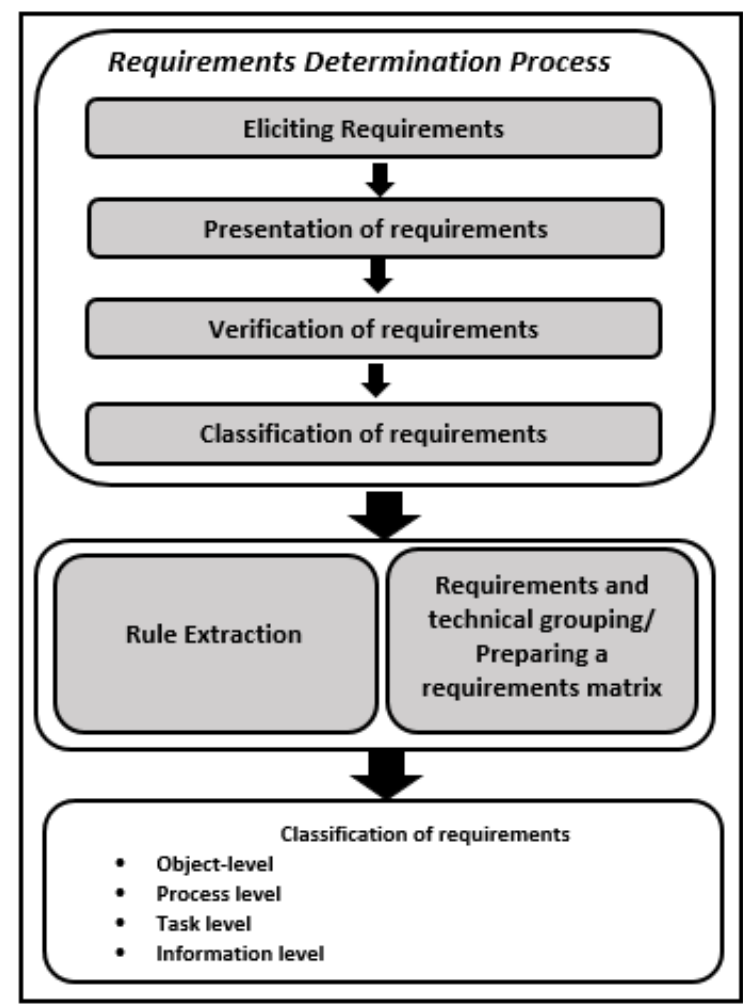

Figure 1. Modeling system requirements [SRM] (Över, 2006; Över Özçelik and Torkul, 2019)

In the third and final stage of the model; For system development studies, a generalized model based on four different need levels and allowing to see a need on the basis of technique/technique combinations have been developed (Över, 2006; Över Özçelik and Torkul, 2019). 


\section{Using SRM in Determining Purchasing System Requirements}

In this section, the sub-processes of SIM; The stages of determining requirements, making rules, creating a technical/requirements matrix, and separating the requirements according to their levels, are explained. The application study was carried out in the Purchasing department of a company that produces wagons. The system requirements model (SRM), whose validity was tested with the pilot application, was applied to the real business environment (Över, 2006; Över Özçelik and Torkul, 2019).

In order to determine the requirements of the new system to be established, a survey was conducted with the employees of the existing system and interviews with senior employees. The handbooks of the current system and some purchasing system software in the market were examined. Matches between problems, products, and processes are provided in order to meet the goals of the desired system and the needs of the users and to produce solutions to existing problems.

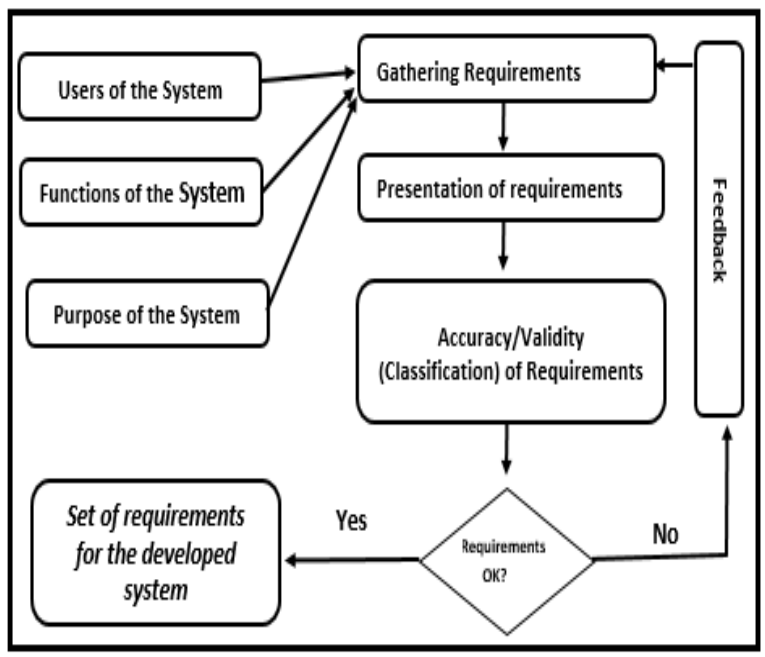

Figure 2. The development process of the new system

This perspective and operation are modeled in Figure 2. In the study, firstly, the existing purchasing system of the enterprise was examined, the problems and malfunctions in the existing structure were determined, it was concluded that a new system should be designed in order to overcome these problems, and for this purpose, the set of requirements required for the new system was determined. It is aimed to design an integrated structure by examining all information flows of the purchasing department with other basic functions within the enterprise. Figure 3 shows the information flows of the purchasing department with other departments. In order to identify and eliminate the problems experienced in the current system, an ideal Purchasing System development study for the enterprise was carried out step by step using SRM.

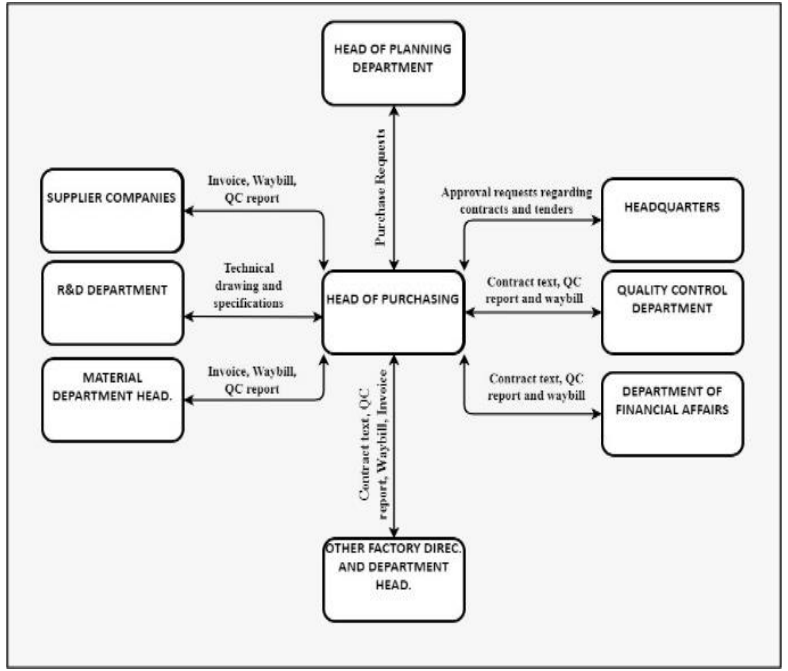

Figure 3. Information flows of the current Procurement System with other basic Functions

\subsection{Eliciting system requirements}

Within the model; Interviews with field experts/users of the system, survey, examination of system procedures/handbooks/documents, needs collection/information gathering process in the light of the software used in the market and literature information was carried out. The reason for using these methods in an integrated manner is to avoid a lack of information in the data collection process. In the information extraction process, 20 system users were used. These are the users of the system in effect at the enterprise.

\subsection{Presentation of System Requirements}

Gathered requirements; Flow chart, Evocative knowledge map, Decision map, Scenario, and Similarity diagram technique were presented, and their validity was confirmed by system users. The arguments put forward during the sessions were grouped and evaluated as needs. The set of confirmed requirements was accepted as the requirement set of the purchasing process, and 40 requirements were determined.

- Presenting the requirements of the purchasing system with the flow diagram technique

These techniques, which were selected based on the literature (Browne and Ramesh, 2002) to overcome the conceptual and behavioral problems seen in all three stages of the requirements assessment process and to improve the needs assessment process, were applied in the following order. In Figure 4, the stages and needs of a purchase request are shown with the flow chart technique. In this process, a total of 14 needs were identified. 


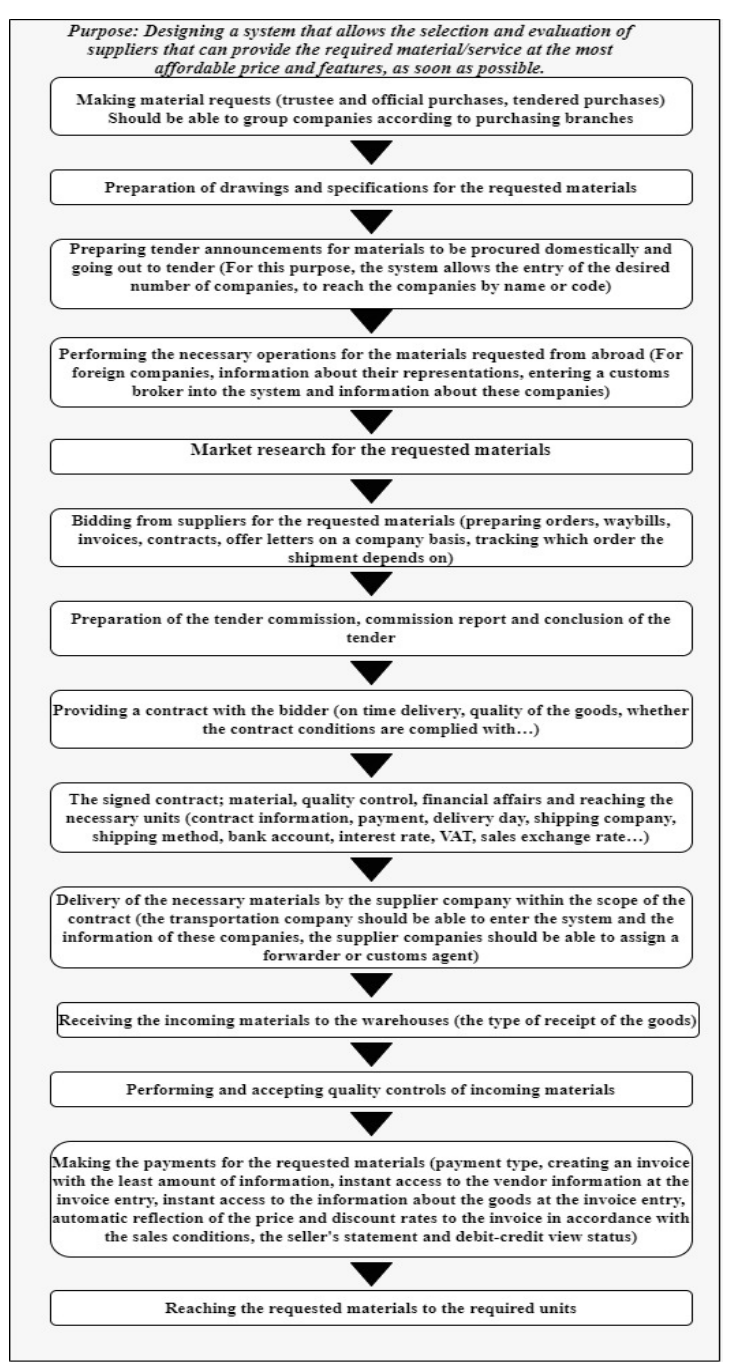

Figure 4. Presentation of requirements with flow chart technique (Över, 2006)

- Presenting the requirements of the purchasing system with the Evocative knowledge map technique

Another technique used in the presentation of the gathered requirements is the Evocative knowledge map technique. Figure 5 shows the evocative information map prepared for the purchase request. With the help of this technique, 9 needs were expressed at the first level and the needs at the second level were ignored based on the expert opinion.

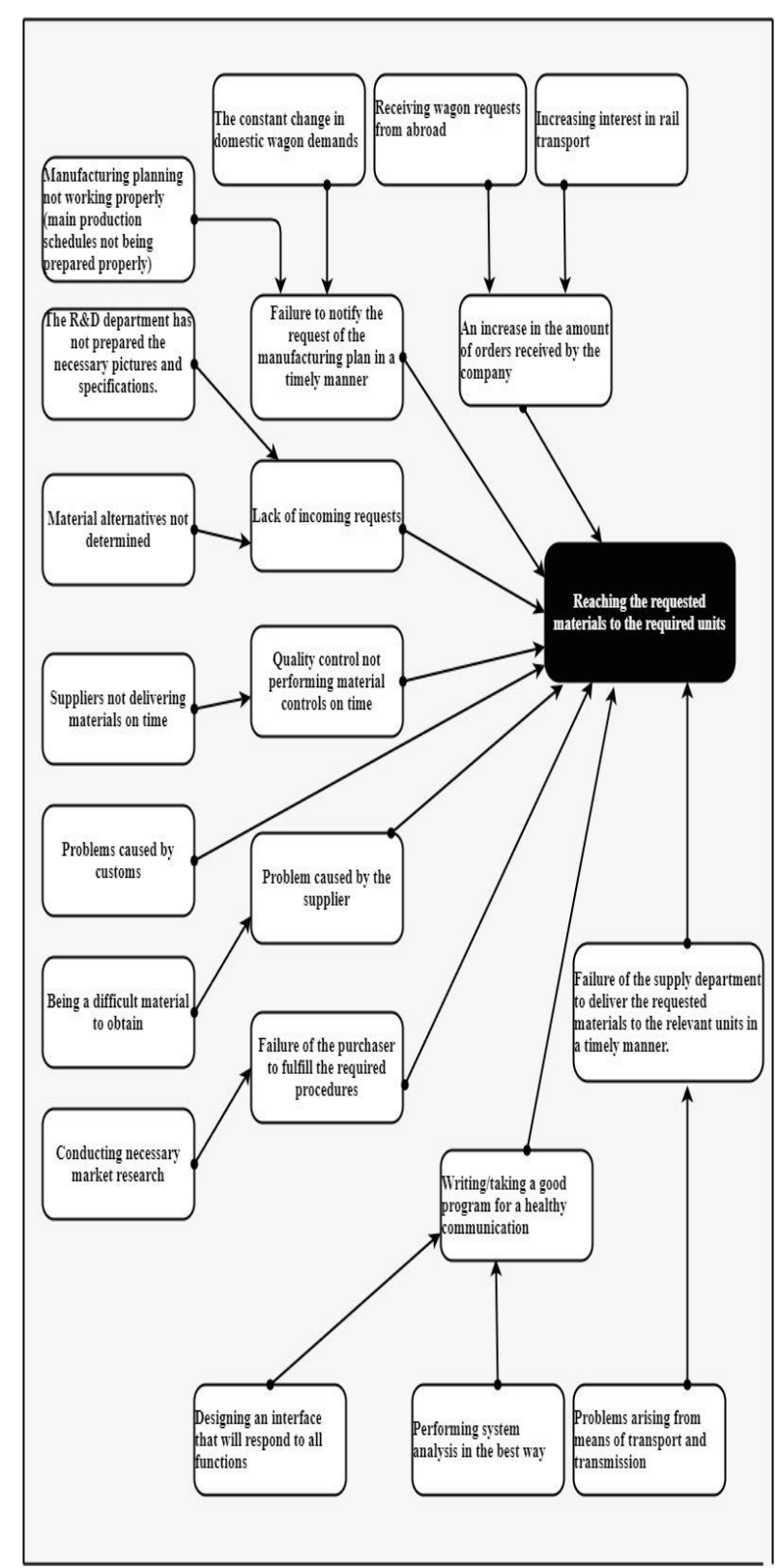

Figure 5. Presentation of requirements with an evocative knowledge map (Över, 2006)

- Presenting the requirements of the purchasing system with the decision mapping technique

The decision mapping technique is one of the preferred techniques to overcome the remembering and communication problems in the information gathering, presentation, and verification stages. A total of 19 requirements were identified with the help of this technique. The decision map prepared in Figure 6 is modeled and shown. 


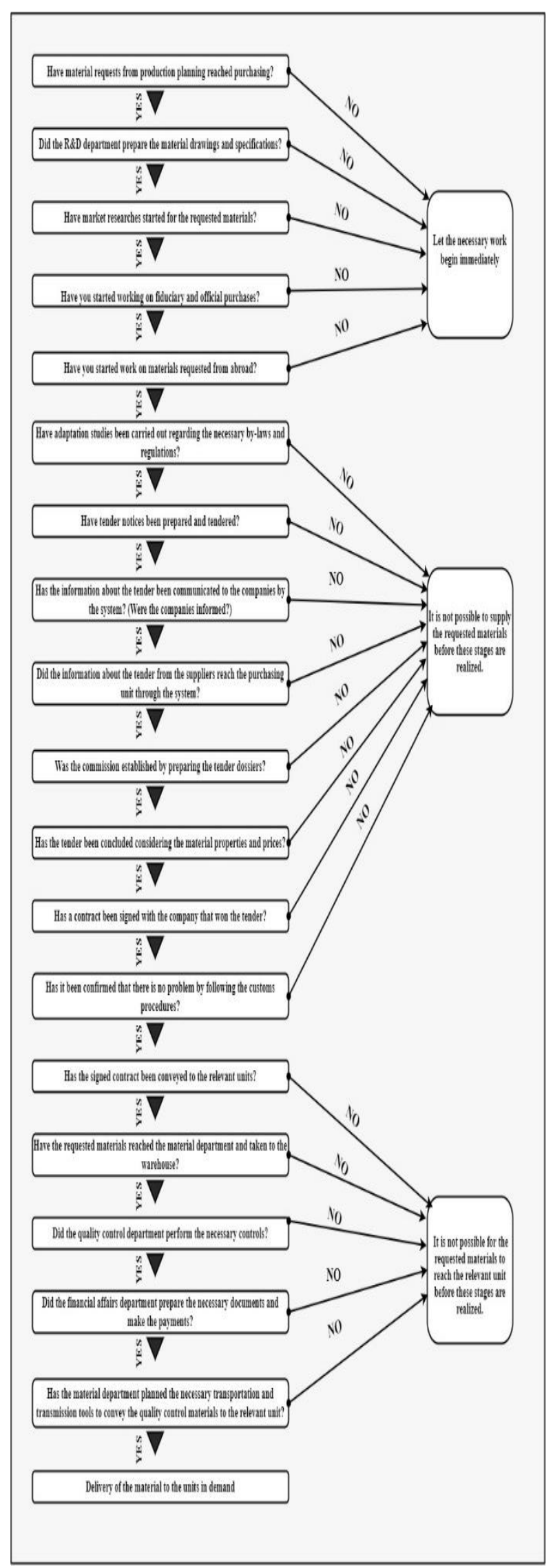

- Presenting the purchasing process requirements using the scenario technique

The scenario technique was preferred and applied based on the literature (Sutcliffe, 2003) to overcome the problems arising from behaviors caused by automated actions. Scenarios consist of events and actors. The scenario written for the purchasing system in the enterprise where the application is made is given below. The requirements were expressed by developing a scenario covering the purchasing process. It was accepted that every activity was carried out as it should be without any problems in this scenario. Within the framework of the planned scenario, new orders to the business were conveyed to Manufacturing Planning by Sales/Marketing, and Manufacturing Planning requested materials from the material department to realize the new orders, but materials that were not available were in question.

For this reason, material requests were sent to purchasing. Let these materials be $\mathrm{x}, \mathrm{y}$, and $\mathrm{z}$. Let $\mathrm{x}$ be a material to be purchased by the trustee. Material $y$ should be a material that requires official purchase, and material $\mathrm{z}$ should be a material that needs to be procured from abroad. Manufacturing Planning should convey the specifications and pictures of these materials to the purchase while requesting these materials' supply because these are important in the appropriate procurement of materials. The system to be designed should include all these situations.

- Presenting the purchasing process requirements using the similarity diagram technique

The similarity diagram was preferred in the information gathering and validation stages to overcome the diversity/complexity of needs and communication problems. To determine the needs by utilizing the similarity diagram technique, first of all, a group of users of the current purchasing system and experienced people in system development was formed. Discussions were organized, and brainstorming was carried out through group sessions. During these sessions, the discussions and speeches regarding the system were systematically noted, and the arguments put forward in the group were listed as shown in Table 2. These arguments, which are given in the form of a table, are arranged in accordance with the logic of the use of the similarity diagram and the sub-systems that should be covered by the system to be realized based on the arguments that have been determined.

Figure 6. Presentation of requirements with the decision map technique (Över, 2006) 
Table 1. Scenario prepared for purchase request (Över, 2006)

\begin{tabular}{|c|c|c|}
\hline $\begin{array}{r}\text { Event } \\
\text { No }\end{array}$ & Actors & Actions \\
\hline 1 & Production planning office: & Requesting materials \\
\hline 2 & R\&D department & $\begin{array}{l}\text { Preparation of drawings and specifications of materials requested by manufacturing } \\
\text { planning }\end{array}$ \\
\hline 3 & $\begin{array}{l}\text { Contract execution and } \\
\text { follow-up officer } \\
\text { foreign trade officer }\end{array}$ & Incoming demand for material $\mathrm{x}$ and $\mathrm{y}$ \\
\hline 4 & $\begin{array}{l}\text { Research tender } \\
\text { preparation branch }\end{array}$ & $\begin{array}{l}\text { Incoming request for material } \mathrm{Z} \text { (To take necessary actions for the supply of } \\
\text { requested materials) }\end{array}$ \\
\hline & supplier & \\
\hline 5 & $\begin{array}{l}\text { Research tender } \\
\text { preparation branch }\end{array}$ & $\begin{array}{l}\text { Conducting market research for the requested materials, preparing tender } \\
\text { announcements, and publishing [Price lists, maturity group, discount rate, and sales } \\
\text { condition information about the products sold by each company, minimum and } \\
\text { maximum order quantities to be received from companies with an order]. }\end{array}$ \\
\hline 6 & Supplier & Bidding of the firms participating in the tender for the requested goods \\
\hline 7 & Rapporteur & Preparing the tender commission and commission report and finalizing the tender \\
\hline 8 & $\begin{array}{l}\text { Contract execution and } \\
\text { follow-up officer } \\
\text { supplier }\end{array}$ & $\begin{array}{l}\text { Preparation of the contract with the companies that won the tender [The system } \\
\text { should give warnings about the companies in line with the information and } \\
\text { impressions when necessary]. [The ability to search by code or name of the goods } \\
\text { for which a purchase request is created, to directly access the detail information of } \\
\text { the goods for which a purchase request is created, to access the previous purchase } \\
\text { request and delivery date of the goods for which a purchase request is created, to } \\
\text { approve the purchase request, to monitor which order the shipment is connected to, } \\
\text { to monitor the stock status in all warehouses at the order entry ]. }\end{array}$ \\
\hline 9 & Supplier & Delivering the requested materials to the company according to the prepared contract \\
\hline 10 & $\begin{array}{l}\text { Contract execution and } \\
\text { follow-up officer }\end{array}$ & $\begin{array}{l}\text { The signed contract; material, quality control, financial affairs and relevant units } \\
\text { [Introductory information of the company (name, title, address, telephone, fax, } \\
\text { capital, product quantity and types, number of workers...), information about } \\
\text { company managers or officials, Containing information about the group or holding } \\
\text { company to which the firm is affiliated]. }\end{array}$ \\
\hline 11 & Material department & Receiving incoming materials to warehouses \\
\hline 12 & Quality control & Performing quality control of incoming materials \\
\hline 13 & Material department & Delivering the requested materials to the required units \\
\hline 14 & Financial affairs & $\begin{array}{l}\text { Carrying out the ordered and incoming materials [Automatic calculation of all } \\
\text { discount and VAT rates, Automatically bringing prices based on companies, goods, } \\
\text { or unique formulas, Calculating the cost in the desired foreign currency]. }\end{array}$ \\
\hline
\end{tabular}


Table 2. Arguments developed within the group for the realization of the purchase request (Över, 2006)

\begin{tabular}{|c|c|}
\hline Person & Arguments \\
\hline Person A) & e need a new system to carry out purchasing transactions and to make healthier decisions regarding this issue. \\
\hline Person B) & $\begin{array}{l}\text { But we don't want a system that will make decisions for us, do we? In other words, we are talking about a system that } \\
\text { will help us decide. In short, we are the ones who will make the final decision. }\end{array}$ \\
\hline Person A) & $\begin{array}{l}\text { You are right, but to make easier and healthier decisions and perform more accessible purchasing functions, we must } \\
\text { organize our choices and define some criteria to facilitate this decision-making task. }\end{array}$ \\
\hline Person C) & $\begin{array}{l}\text { In addition, the criteria we use must be consistent with each other. I think that the criteria we will determine will be } \\
\text { of great importance in evaluating the performance of suppliers. }\end{array}$ \\
\hline Person A) & $\begin{array}{l}\text { An interface should be designed so that it allows us to perform all our functions in the best possible way. E.g., Ability } \\
\text { to perform company transactions in the desired foreign currency (calculation ability), group companies according to } \\
\text { certain features and sectors, prepare orders, delivery notes, invoices, contracts, letters of offer based on companies, } \\
\text { define the account code of the company, define the desired number of addresses for shipment or document sending to } \\
\text { companies should include fields such as }\end{array}$ \\
\hline Person B) & $\begin{array}{l}\text { I think this interface is more the work of the program, so system analysis should be done very well so that the } \\
\text { requirements of the whole system can be determined and the system will respond to all our requests. }\end{array}$ \\
\hline Person E) & $\begin{array}{l}\text { I believe it will be very beneficial for us in keeping our data in electronic form. In this way, we will avoid keeping } \\
\text { repetitive data through a shared database. }\end{array}$ \\
\hline Person A) & 1, \\
\hline Person E) & $\begin{array}{l}\text { Then we can start by determining the fields in the system interface, the criteria, and the reports we intend to receive } \\
\text { from the system, for example; An interface should be designed that allows us to see the previous orders and delivery } \\
\text { dates of the ordered goods, the final delivery and delivery date of the order, the authorized person who placed the } \\
\text { order, the opportunity to distribute the orders to different companies, the opportunity to see important messages about } \\
\text { the seller at the order entry and to determine the order priority, and to evaluate the companies based on these. . }\end{array}$ \\
\hline Person D) & $\begin{array}{l}\text { If we enter the goods/services to be supplied to this system, is it possible for the system to give us the criteria for this } \\
\text { good/service? }\end{array}$ \\
\hline Person A) & $\begin{array}{l}\text { The criteria, which are essential to us and that we have determined before, must be entered into the system. Therefore, } \\
\text { when we enter the goods/services to be procured into the system, it is possible to access its criteria and other } \\
\text { information. }\end{array}$ \\
\hline Perso & \\
\hline Person A) & ize what we are \\
\hline Person E) & $\begin{array}{l}\text { I read somewhere that some simple expert systems can make more effective decisions than managers in making } \\
\text { decisions about the goods/services to be procured. }\end{array}$ \\
\hline Person F) & $\begin{array}{l}\text { An expert system or decision support system may not be suitable for us. Because; we are an official institution, and } \\
\text { we can't depend only on such systems while making some decisions. }\end{array}$ \\
\hline Person C) & $\begin{array}{l}\text { I do not know that, and I do not trust computers that can make such decisions. In addition, some situations require us } \\
\text { to make decisions independently of the system due to urgent conditions such as public procurement laws and } \\
\text { regulations. }\end{array}$ \\
\hline Person A) & $\begin{array}{l}\text { We need a system that puts the decisions in order but leaves the final choice up to us; you know, this is a decision } \\
\text { support system. Because, thanks to the reports we get from here, we can make healthier decisions. } \\
\text { In other words, we will tell the system which criteria we should use, and it will give us the information that will enable } \\
\text { us to decide which goods/services we can obtain at what time and at what price, and from where? }\end{array}$ \\
\hline Person E) & $\begin{array}{l}\text { I know that; Expert systems have advantages in terms of consistent use of criteria; we should use them consistently, } \\
\text { make fair decisions, and get the most appropriate goods/services. }\end{array}$ \\
\hline Person F) & $\begin{array}{l}\text { We need a system that puts the decisions in order but leaves the final choice up to us; you know, this is a decision } \\
\text { support system. Because, thanks to the reports we get from here, we can make healthier decisions. }\end{array}$ \\
\hline Person A) & $\begin{array}{l}\text { Yes, I agree; I think that a computer cannot fully evaluate some conditions and features for suppliers. } \\
\text { It's easy; then, we'll put these exceptions and features into a scoring system. }\end{array}$ \\
\hline Person C) & $\begin{array}{l}\text { In other words, we will tell the system which criteria we should use, and it will give us the information that will enable } \\
\text { us to decide which goods/services we can obtain, for what time and at what price, and from where? }\end{array}$ \\
\hline
\end{tabular}

During the sessions, the arguments were grouped according to the system they covered or what they expressed, and the statements in the groups were evaluated as requirements. The structure and similarity diagram technique of all these systems/subsystems and the needs of a purchasing process are given in Figure 7.

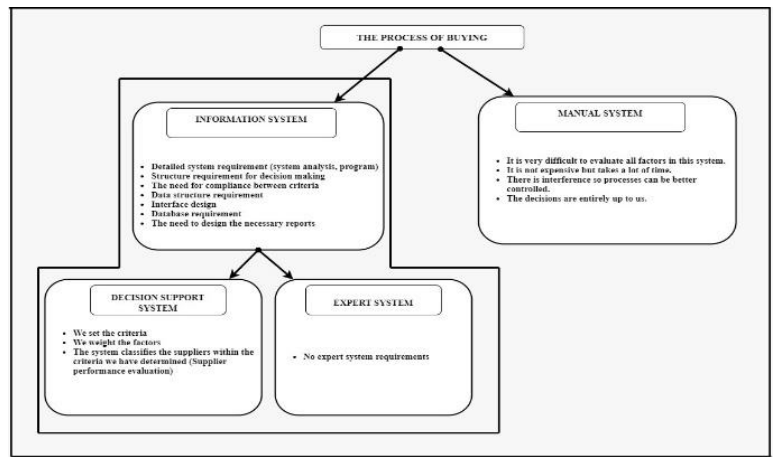

Figure 7. Presentation of requirements with similarity diagram technique (Över, 2006) 
Table 3. Identified requirements and techniques used for purchase request (Över, 2006), [Requirements 1/16]

Techniques

\begin{tabular}{|c|c|c|c|c|c|c|}
\hline $\begin{array}{l}\text { Requ. } \\
\text { No }\end{array}$ & Requirements & $\begin{array}{l}\text { Flow } \\
\text { diagram }\end{array}$ & $\begin{array}{l}\text { Evocative } \\
\text { knowledge map }\end{array}$ & $\begin{array}{l}\text { Decision } \\
\text { map }\end{array}$ & $\begin{array}{l}\text { Scenario } \\
\text { technique }\end{array}$ & $\begin{array}{l}\text { Similarity } \\
\text { diagram }\end{array}$ \\
\hline 1 & Requesting materials & $*$ & & $*$ & $*$ & \\
\hline 2 & $\begin{array}{l}\text { Preparation of drawings } \\
\text { and specifications of } \\
\text { materials requested by } \\
\text { manufacturing planning }\end{array}$ & $*$ & & $*$ & $*$ & \\
\hline 3 & $\begin{array}{l}\text { Incoming demand for } \\
\text { material } x \text { and } y \\
\text { (Preparing tender notices } \\
\text { for materials to be } \\
\text { procured domestically } \\
\text { and bidding) }\end{array}$ & $*$ & & $*$ & $*$ & \\
\hline 4 & $\begin{array}{l}\text { Incoming request for } \\
\text { material } \mathrm{Z} \text { (To take } \\
\text { necessary actions for the } \\
\text { supply of materials } \\
\text { requested from abroad) }\end{array}$ & $*$ & & $*$ & $*$ & \\
\hline 5 & $\begin{array}{l}\text { Conducting market } \\
\text { research for the requested } \\
\text { materials }\end{array}$ & $*$ & & $*$ & $*$ & \\
\hline 6 & $\begin{array}{l}\text { Bidding of the firms } \\
\text { participating in the tender } \\
\text { for the requested goods }\end{array}$ & $*$ & & $*$ & $*$ & \\
\hline 7 & $\begin{array}{l}\text { Preparing the tender } \\
\text { commission } \\
\text { commission report and } \\
\text { finalizing the tender }\end{array}$ & $*$ & & $*$ & $*$ & \\
\hline 8 & $\begin{array}{l}\text { Preparing the contract } \\
\text { with the companies } \\
\text { where the tender } \\
\text { remained }\end{array}$ & $*$ & & $*$ & $*$ & \\
\hline 9 & $\begin{array}{l}\text { The signed contract; To } \\
\text { ensure that it reaches the } \\
\text { material, quality control, } \\
\text { financial affairs, and } \\
\text { related units }\end{array}$ & $*$ & & $*$ & $*$ & \\
\hline 10 & $\begin{array}{l}\text { Delivering the requested } \\
\text { materials to the company } \\
\text { according to the prepared } \\
\text { contract }\end{array}$ & $*$ & & $*$ & $*$ & \\
\hline 11 & $\begin{array}{l}\text { Receiving incoming } \\
\text { materials to warehouses }\end{array}$ & $*$ & & $*$ & $*$ & \\
\hline 12 & 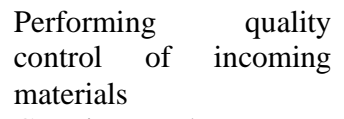 & $*$ & & $*$ & $*$ & \\
\hline 13 & $\begin{array}{l}\text { Carrying out the payment } \\
\text { transactions of the } \\
\text { requested and incoming } \\
\text { materials }\end{array}$ & $*$ & & $*$ & $*$ & \\
\hline 14 & $\begin{array}{l}\text { Delivering the requested } \\
\text { materials to the required } \\
\text { units }\end{array}$ & $*$ & & $*$ & $*$ & \\
\hline 15 & $\begin{array}{l}\text { An increase in the } \\
\text { number of orders } \\
\text { received by the company }\end{array}$ & & $*$ & & & \\
\hline 16 & $\begin{array}{l}\text { Manufacturing } \\
\text { scheduling not reporting } \\
\text { the request on time }\end{array}$ & & $*$ & & & \\
\hline
\end{tabular}


Continuation of Table 3. The requirements and techniques used for the purchase request [Requirements No. 17/40]

\begin{tabular}{|c|c|c|c|c|c|c|}
\hline \multirow{3}{*}{$\begin{array}{l}\text { Requ. } \\
\text { No }\end{array}$} & \multirow{3}{*}{ Requirements } & \multicolumn{5}{|c|}{ Techniques } \\
\hline & & & & & & \\
\hline & & $\begin{array}{l}\text { Flow } \\
\text { diagram }\end{array}$ & $\begin{array}{l}\text { Evocative } \\
\text { knowledge map }\end{array}$ & $\begin{array}{l}\text { Decision } \\
\text { map }\end{array}$ & $\begin{array}{l}\text { Scenario } \\
\text { technique }\end{array}$ & $\begin{array}{l}\text { Similarity } \\
\text { diagram }\end{array}$ \\
\hline 17 & Lack of incoming requests & & $*$ & & & \\
\hline 18 & $\begin{array}{l}\text { Quality control not performing } \\
\text { material controls on time }\end{array}$ & & $*$ & & & \\
\hline 19 & $\begin{array}{l}\text { The problem caused by } \\
\text { customs }\end{array}$ & & $*$ & & & \\
\hline 20 & $\begin{array}{l}\text { The problem caused by the } \\
\text { supplier }\end{array}$ & & $*$ & & & \\
\hline 21 & $\begin{array}{l}\text { Failure of the purchaser to } \\
\text { fulfill the required procedures }\end{array}$ & & $*$ & & & \\
\hline 22 & $\begin{array}{l}\text { Failure of the supply } \\
\text { department to deliver the } \\
\text { requested materials to the } \\
\text { relevant units in a timely } \\
\text { manner. }\end{array}$ & & $*$ & & & \\
\hline 23 & $\begin{array}{l}\text { Writing/taking a good program } \\
\text { for a healthy communication }\end{array}$ & & $*$ & & & \\
\hline 24 & $\begin{array}{l}\text { Have you started to work on } \\
\text { fiduciary and official } \\
\text { purchases? }\end{array}$ & & & $*$ & & \\
\hline 25 & $\begin{array}{l}\text { Have adaptation studies been } \\
\text { carried out regarding the } \\
\text { necessary by-laws } \\
\text { regulations? }\end{array}$ & & & $*$ & & \\
\hline 26 & $\begin{array}{l}\text { Has the information about the } \\
\text { tender been communicated to } \\
\text { the companies by the system? }\end{array}$ & & & $*$ & & \\
\hline 27 & $\begin{array}{l}\text { Did the information about the } \\
\text { tender from the suppliers reach } \\
\text { the purchasing unit through the } \\
\text { system? }\end{array}$ & & & $*$ & & \\
\hline 28 & $\begin{array}{l}\text { Has the material department } \\
\text { planned the necessary } \\
\text { transportation and } \\
\text { transmission tools to convey } \\
\text { the quality control materials to } \\
\text { the relevant unit? }\end{array}$ & & & $*$ & & \\
\hline 29 & Detailed system requirement & & & & & $*$ \\
\hline 30 & $\begin{array}{l}\text { Structure requirement for } \\
\text { decision making }\end{array}$ & & & & & $*$ \\
\hline 31 & $\begin{array}{l}\text { The requirement for agreement } \\
\text { between criteria }\end{array}$ & & & & & $*$ \\
\hline 32 & Data structure requirement & & & & & $*$ \\
\hline 33 & We set the criteria & & & & & $*$ \\
\hline 34 & We weigh the factors & & & & & * \\
\hline 35 & No expert system requirements & & & & & $*$ \\
\hline 36 & $\begin{array}{l}\text { The system classifies the } \\
\text { suppliers within the criteria we } \\
\text { have determined (Supplier } \\
\text { performance) }\end{array}$ & & & & & * \\
\hline 37 & Fatabase requirement & & & & & * \\
\hline 38 & Interface design requirements & & & & & * \\
\hline 39 & $\begin{array}{l}\text { Identifying information } \\
\text { formats }\end{array}$ & & & & & $*$ \\
\hline 40 & $\begin{array}{l}\text { The need to design the } \\
\text { necessary reports }\end{array}$ & & & & & $*$ \\
\hline & Identified requirement in total & $14 / 40$ & $9 / 40$ & $19 / 40$ & $14 / 40$ & $12 / 40$ \\
\hline
\end{tabular}

Table 3; includes requirement numbers, needs identified for the purchasing process, and identifying techniques. For example, need No. 1; presented by the flowchart, decision map, and scenario technique. 
Asterisks (*) corresponding to the needs under the Techniques indicate by which methods the requirements are presented. Any requirement that was presented by several techniques at the stage of creating the needs set was accepted as if it was presented only once. When evaluated in this way, the purchasing process needs to set 40 elements.

\subsection{Verification of system requirements}

At this stage, the requirements expressed with integrated techniques were examined by the employees of the purchasing department or analysts with knowledge of the purchasing system, and their accuracy and validity were decided. For this purpose, first of all, an informative study was carried out on the need for presentation techniques to the system users, namely field experts. Later, the requirements that were transferred to the presentation techniques were examined by 12 purchasing system users (field experts) and 12 experienced analysts in the sessions held. These sessions were held in ten sessions, twice for each presentation technique. Sessions for each presentation technique lasted approximately 45 minutes. It has been decided that the system is sufficient to meet all the requirements of the system by the users and expert analysts.

Their field knowledge for system users and their experience for analysts have an important place in this verification. The output of this stage is the set of requirements of the system required to be installed to realize the purchase request. The elements of this cluster consist of 40 needs identified with the help of presentation techniques. The most critical issue to be considered in system development studies is determining the system needs most wholly and accurately. Because the functions of the system and the realization of the users' wishes or reaching the goal are based on a correctly and completely determined set of needs. Therefore, these needs need to be measured with a method. For this purpose, a template for need classes was used in the study.

\subsection{Classification of the requirements identified for the system}

Identifying requirements is seen as the most important step in the successful conclusion of information system development studies. For this reason, the most crucial issue to be considered in system development studies is to determine the system needs most accurately and completely. Realizing system functions and user requests or reaching the goal is only possible with a wholly and correctly determined set of needs. For this purpose, it is suggested that these verified needs should be measured by a method (Browne and Pitts, 2004). In the study, a template for the need classes suggested in the literature was used, so it was possible to decide on the completeness of the need set.

The classification includes four different levels.
Needs are classified according to these four different levels and their sub-levels, confirming their completeness and completeness. Table 4 below shows the distribution of the requirements determined for the purchasing system at four primary levels. These levels are; purpose, process, task, and informatics. The needs expressed through presentation techniques are given in need classes based on their sequence numbers.

Table 4. Classification of the requirements determined for the purchasing system according to their levels

\begin{tabular}{|c|c|}
\hline Requirement Levels & Requirement Numbers \\
\hline $\begin{array}{l}\text { Goal Level } \\
\text { Requirements }\end{array}$ & $\begin{array}{c}1,5,6,8,12,15,16,17,18 \\
20,21,22,23,25\end{array}$ \\
\hline $\begin{array}{ll}\text { Process } & \text { Level } \\
\text { Requirements } & \end{array}$ & $3,4,9,10,14$ \\
\hline $\begin{array}{l}\text { Task-level } \\
\text { requirements }\end{array}$ & $2,7,11,13,19,24,26,27,28$ \\
\hline $\begin{array}{l}\text { Information Level } \\
\text { Requirements }\end{array}$ & $\begin{array}{c}29,30,31,32,33,34,35,36 \\
37,38,39,40\end{array}$ \\
\hline
\end{tabular}

When the 40 requirements that make up the purchasing system needs are classified as general need levels, purpose, process, task, and information level, 14 of them were objective, 5 were processed, 9 were task, and 12 were informatics. The requirements set of the purchase request were classified using the general need level template and then the lower levels of this general level template. It was time to implement the second stage of the model. At this stage, the ROC algorithm was used in grouping the purchasing system requirements.

\subsection{Using the ROC Algorithm to Determine System Requirements}

In the second stage, the need/presentation techniques were grouped, and the families of requirements were formed, and the determination of which techniques were more effective in determining the number of needs, and the rates of determination of the requirements determined based on the technique/technical combination were carried out. For this purpose, the ROC algorithm was used (Över, 2006; Över Özçelik and Torkul, 2019; King, 1980].

\section{- Creating a requirement/presentation techniques matrix for the system}

According to the ROC algorithm application logic; After running the algorithm by arranging rows and columns, with the help of the requirements/presentation technique matrix whose elements are $0-1$, to gather similar needs together and thus to group presentation techniques to form clusters on the diagonal axis of the matrix. In this way, just as machine groups and part 
families are formed by bringing together the same operations by the logic of group technology, need families, and technical groups are formed in this study due to the same logic. Due to the group technology application logic, there is a certain number of parts and a certain number of machines. A certain number of needs are identified in this study, and a certain number of techniques are used to determine them. Just as a certain logic is used during a system development work, even if it serves many different purposes, the system is developed, and its users have particular needs. In this study, to determine these general needs, it has been tried to select the technique/technical combinations to express them. The ROC algorithm also helps in this regard.

While applying the ROC algorithm in the study, matrices were used, need determination techniques were placed in the matrix rows, and determining requirements were placed in the columns. Figure $8 \mathrm{a}$ and Figure $8 \mathrm{~b}$ below, $\mathrm{T} 1$ and $\mathrm{T} 2$ show the techniques used to determine needs, and P1, P2, P3, P4, and P5 indicate the needs. techniques; T1, T2, T3,...Tn, the requirements are; It is expressed as $\dot{\mathrm{I}} 1, \dot{\mathrm{I}} 2, \dot{\mathrm{I}} 3, \ldots . . . \mathrm{In}$. For example, if the T1 technique determines the need for I1, "1" is written; if not, " 0 " is written. In this way, the requirements determined by all techniques are entered in order. By running the ROC algorithm, similar needs come together due to the working logic of the algorithm and requirement families. Technical/technical combinations are created that follow each other diagonally.

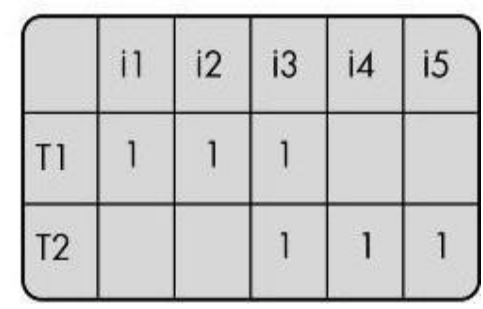

Figure 8a. ROC algorithm was applied to the combination of T1-T2 techniques.

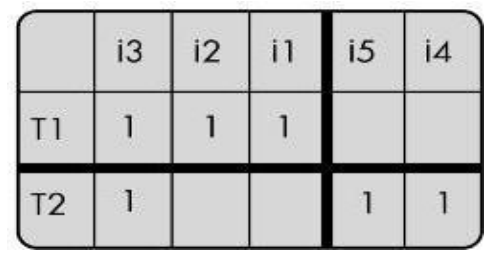

Figure 8b. ROC algorithm applied to the combination of T1$\mathrm{T} 2$ techniques.

Figure $8 \mathrm{~b}$ was obtained by applying the ROC algorithm to the matrix formed by the use of $\mathrm{T} 1$ (flow chart) and T2 (connotation information map) techniques in Figure 8a. As shown in Figure 8b, the requirements I1, I2, I3 are expressed by the T1 technique from the requirement family/group 1 , while the needs I4, I5 are defined by the $\mathrm{T} 2$ technique from the need family/group 2.

\section{- Evaluation of requirements identification success} criteria for the system

The pilot application uses the ROC algorithm [35, 36]; It has been observed which technique/technical combinations determine which level requirements and technique/technical combinations determine all needs. The success criteria developed within the model's scope were used to evaluate the created need groups and technical groups belonging to the purchasing system needs (Över, 2006; Över Özçelik and Torkul, 2019).

These success criteria are;

- Need Determination Efficiency Measure of Techniques $\left(t_{e}\right)$

- Need Verification Efficiency Measure of Techniques $\left(t_{v}\right)$ and

- Average Technical Efficiency Measure $\left(t_{o v}\right)$.

In Table 5, Table 6, Table 7, and Table 8 below, the Requirements Determination Efficiency Measure of Techniques $\left(t_{v}\right)$, Needs Verification Efficiency Measure of Techniques $\left(t_{o v}\right)$, and Average Technical Efficiency Measure $\left(t_{o v}\right)$ values for the purchasing system are given. Symbols T1 represents the flowchart, Associative information map T2, Decision map T3, Scenario technique T4 and Affinity diagram technique T5. As mentioned above, the values calculated through Success Criteria for Determining System Requirements are arranged and tabulated, techniques/technique combinations are given in the first column, values in the second column, values in the third column, and values in the fourth column. Table 5 below shows the success criteria values obtained by using only the techniques for the purchase request. Here, the values of $t_{e}, t_{v}$ and $t_{O V}$ for five techniques that are valid within the scope of the model are given.

Table 5. Success criteria for purchase requisition calculated using only techniques

\begin{tabular}{cccc}
\hline $\begin{array}{c}\text { Tech./Tech. } \\
\text { Combinations }\end{array}$ & $t_{\boldsymbol{e}}$ & $\boldsymbol{t}_{\boldsymbol{v}}$ & $\boldsymbol{t}_{\boldsymbol{O} \boldsymbol{v}}$ \\
\hline $\mathrm{T} 1$ & 0.35 & 0 & 0.35 \\
$\mathrm{~T} 2$ & 0.22 & 0 & 0.22 \\
$\mathrm{~T} 3$ & $0.4 \varepsilon$ & 0 & 0.48 \\
$\mathrm{~T} 4$ & 0.35 & 0 & 0.35 \\
$\mathrm{~T} 5$ & $0.3 \mathrm{C}$ & 0 & 0.30 \\
\hline
\end{tabular}

In Table 8, Flowchart/Associative information map/Decision map/Similarity diagram, Associative information map/Decision map/Scenario/Similarity diagram techniques, which have the highest value among the need identification efficiency measure $t_{e}$ values of the techniques (T1-T2- T3-T5), (T2-T3-T4T5) and (T1-T2-T3-T4-T5) combinations formed by the use of Flowchart, Associative information map, Decision map, Scenario and Similarity diagram 
techniques 1.00 to 40 determined all your requirements. The combination of T1-T2-T3-T4, which is formed by using the techniques as a quadruple, determined 28 needs with its lowest value.

Requirements verification efficiency measure of techniques $\left(t_{v}\right)$ Flowchart / Associative information map / Decision map diagram / Scenario, Flowchart / Decision map diagram / Scenario / Similarity diagram (T1-T2-T3-T4), (T1-T3-T4-T5) ) techniques in four and using a combination of Flowchart, Associative information map, Decision map, Scenario and Similarity diagram techniques (T1-T2-T3-T4-T5) techniques in a quintet, between 0.70 and 14 repetitive needs were determined. T1-T2-T3-T5 and T2-T3-T4-T5 technical combinations take the highest value of 0.25 for the average efficiency measure value $t_{O V}$ of the techniques and $25 \%$ of the needs per technique T1-T2-T3-T4-T5 technical combination. It was seen that it determined $20 \%$ of the needs per technique with 0.20 .
3.6. Inductive Learning Approach and Use of RULES-3 Algorithm

The second stage of the SRM involves creating a need/needs determination techniques matrix and parallel with the rulemaking. With the application of the ROC algorithm, the response was obtained to determine which technique/technique combination is effective in determining the needs, the number of repetitive requirements accepted as need verification, and the amount of need determined by each technique on average. But the aim of the study lies in finding out which techniques determine the need at which level and to what extent. However, it is not possible to see this clearly by applying the ROC algorithm. In addition, it is aimed to use need levels as stopping rules in the study. For this purpose, the RULES-3 algorithm was also used in parallel with ROC in the second stage of SRM.

Table 9. The training set obtained for the purchasing system

\begin{tabular}{|c|c|c|c|c|c|}
\hline \multirow[t]{2}{*}{$\begin{array}{l}\text { Techniques/ } \\
\text { Combinations }\end{array}$} & $\begin{array}{r}\text { Characteristic } \\
\text { Goal level } \\
\left(W_{1:} 0.36\right) \\
\end{array}$ & $\begin{array}{c}\text { Characteristic } \\
\text { Process level } \\
\left(W_{2:} \text { 0.14) }\right. \\
\end{array}$ & $\begin{array}{c}\text { Characteristic } \\
\text { Task level } \\
\left(W_{3:} \text { 0.18) }\right. \\
\end{array}$ & $\begin{array}{c}\text { Characteristic } \\
\text { Information level } \\
\left(W_{4:} 0.32\right) \\
\end{array}$ & Class Range \\
\hline & $\begin{array}{l}\text { Linguistic } \\
\text { Expression }\end{array}$ & $\begin{array}{l}\text { Linguistic } \\
\text { Expression }\end{array}$ & $\begin{array}{l}\text { Linguistic } \\
\text { Expression }\end{array}$ & $\begin{array}{l}\text { Linguistic } \\
\text { Expression }\end{array}$ & $\begin{array}{l}\text { Linguistic } \\
\text { Expression }\end{array}$ \\
\hline T1 & $\mathbf{L}$ & VH & $\mathbf{N}$ & VL & NM \\
\hline $\mathbf{T 2}$ & $\mathbf{N}$ & VL & VL & VL & NM \\
\hline T3 & $\mathbf{N}$ & VH & VH & VL & LM \\
\hline $\mathbf{T 4}$ & $\mathbf{L}$ & VH & $\mathbf{N}$ & VL & NM \\
\hline T5 & VL & VL & VL & VH & NM \\
\hline T1-T2 & VH & VH & $\mathbf{N}$ & VL & $\mathbf{P M}$ \\
\hline T1-T3 & $\mathbf{N}$ & VH & VH & VL & LM \\
\hline T1-T4 & $\mathbf{L}$ & VH & $\mathbf{N}$ & VL & NM \\
\hline T1-T5 & $\mathbf{N}$ & VH & $\mathbf{N}$ & VH & PM \\
\hline T2-T3 & VH & VH & VH & VL & PM \\
\hline T2-T4 & VH & VH & $\mathbf{N}$ & VL & $\mathbf{P M}$ \\
\hline T2-T5 & $\mathbf{N}$ & VL & VL & VH & $\mathbf{P M}$ \\
\hline T3-T4 & $\mathbf{N}$ & VH & VH & VL & LM \\
\hline T3-T5 & $\mathbf{N}$ & VH & VH & VH & MM \\
\hline T4-T5 & $\mathbf{L}$ & VH & $\mathbf{N}$ & VH & PM \\
\hline T1-T2- T3 & VH & VH & VH & VL & PM \\
\hline T1- T2- T4 & VH & VH & $\mathbf{N}$ & VL & PM \\
\hline T1- T2- T5 & VH & VH & $\mathbf{N}$ & VH & MM \\
\hline T1- T3- T4 & $\mathbf{N}$ & VH & VH & VL & LM \\
\hline T1- T3- T5 & $\mathbf{N}$ & VH & VH & VH & MM \\
\hline T1- T4- T5 & $\mathbf{L}$ & VH & $\mathbf{N}$ & VH & PM \\
\hline T2- T3- T4 & VH & VH & VH & VL & PM \\
\hline T2- T3- T5 & VH & VH & VH & VH & FM \\
\hline T2- T4- T5 & VH & VH & $\mathbf{N}$ & VH & MM \\
\hline T3- T4- T5 & $\mathbf{N}$ & VH & VH & VH & MM \\
\hline T1-T2-T3-T4 & VH & VH & VH & VL & PM \\
\hline T1-T2- T3-T5 & VH & VH & VH & VH & FM \\
\hline T1-T2- T4-T5 & VH & VH & $\mathbf{N}$ & VH & MM \\
\hline T1-T3-T4-T5 & $\mathbf{N}$ & VH & VH & VH & MM \\
\hline T2- T3-T4-T5 & VH & VH & VH & VH & FM \\
\hline T1-T2- T3-T4-T5 & VH & VH & VH & VH & NM \\
\hline
\end{tabular}

Inductive learning aims at a specific-to-general approach. In this study, starting from a specific example, a model that can be used in whole general system development studies is proposed, and an inductive 
learning approach is preferred (Aksoy, 2005/113-120). In using the inductive learning approach, the output is either a decision tree or a set of rules. What is expected from an inductive learning algorithm is to obtain the most general rules possible. Because; These decision trees or rules will guide the system development studies in all different areas that will be carried out later. One of the algorithms used for this purpose is the RULES-3 algorithm (Aksoy, 2005/113-120; Aksoy, 2005/121132). The preference of this algorithm is that it can classify the most samples by checking the obtained rules one by one and select the most general rules.

The steps to be realized during the implementation of the inductive learning approach and the RULES-3 algorithm were applied step by step as given below.

- Determination of samples,

- Calculation of the representative values of the characteristics of the samples,

- Assigning these representation values to defined class ranges,

- Weighting of the characteristics,

- Determining the class values of the samples,

- Assignment of linguistic variables corresponding to numeric values,

- Creation of the training set after all the above steps and

- It is the extraction of rules from the training set with the help of the RULES-3 algorithm.

As a result of these steps, a training set with 31 examples was prepared, consisting of 5 techniques and combinations of these techniques with $2,3,4$, and 5 . While creating the training set, four different characteristics were used. These express need levels and are named as purpose, process, task, and informatics. These characteristics must have certain weights or degrees of importance due to the RULES-3 algorithm usage logic. These degrees of importance were determined based on the literature.

In the literature, the requirements are divided into four general levels: goal, task, process, and informatics. Also, goal-level needs are divided into ten sub-levels, process-level needs 4, task-level needs 5, and information-level needs nine sub-levels. These sublevels were collected and accepted as 28 basic needs. Based on this acceptance, the weight falling on each need class has been determined. In this study, it has been accepted that all of these requirement definitions represent a need, they constitute a set of needs, and all of them are equal to 1 . Based on this acceptance and evaluation, the weight of each requirement is 0.036 . This ratio is multiplied by the number of needs per general class and for the purpose; 0.36 for the process; 0.14 for the task; 0.18 and informatics; It was found to be 0.32 .

Characteristics/requirements are expressed numerically first, and then these numerical values are transformed into linguistic expressions by giving specific definition ranges (Över, 2006; Över Özçelik and Torkul, 2019). As a result of all these stages, a training set was created for the purchasing system shown in Table 9. (linguistic expressions; Low/L, Normal/N, Very low/VL, Very high/VH, Never met/NM, Partially Met/PM, Fully Met/FM, Most Met/MM, Little Met/LM). The RULES-3 algorithm was used to transform the information in training set into regular rules. The rules obtained here can be used in the classification of new samples in future studies without the need for a training set. The rules produced by the RULES-3 algorithm are given in Table 10.

Table 10. Rules generated by the RULES-3 algorithm (Över, 2006)

\begin{tabular}{|c|c|}
\hline & if; goal $\mathrm{N}$ and process VL and task VL and information VL in case Class NM \\
\hline Rule 2 & if; goal VL and process VL and task VL and information VH in case Class NM \\
\hline Rule 3 & if; goal $\mathrm{L}$ and process $\mathrm{VH}$ and task $\mathrm{N}$ and information VL in case Class NM \\
\hline Rule 4 & if; goal $\mathrm{N}$ and process $\mathrm{VH}$ and task $\mathrm{N}$ and information $\mathrm{VH}$ in case Class $\mathrm{PM}$ \\
\hline Rule 5 & if; goal $\mathrm{N}$ and process VL and task VL and information VH in case Class PM \\
\hline Rule 6 & if; goal VH and process $\mathrm{VH}$ and task $\mathrm{N}$ and information VL in case Class PM \\
\hline Rule 7 & if; goal $\mathrm{N}$ and process $\mathrm{VH}$ and task $\mathrm{VH}$ and information VL in case Class LM \\
\hline Rule 8 & if; goal $\mathrm{L}$ and process $\mathrm{VH}$ and task $\mathrm{N}$ and information $\mathrm{VH}$ in case Class PM \\
\hline Rule 9 & if; goal VH and process and task VH and information VL in case Class PM \\
\hline Rule 10 & if; goal VH and process $\mathrm{VH}$ and task $\mathrm{N}$ and information $\mathrm{VH}$ in case Class $\mathrm{MM}$ \\
\hline Rule 11 & if; goal $\mathrm{N}$ and process $\mathrm{VH}$ and task $\mathrm{VH}$ and information $\mathrm{VH}$ in case Class $\mathrm{MM}$ \\
\hline Rule 12 & if; goal VH and process $\mathrm{VH}$ and task $\mathrm{VH}$ and information VH in case Class FM \\
\hline
\end{tabular}


In the proposed model, by using the techniques together, the requirement determination rates of the techniques were measured, the analogy was realized with the help of an algorithm that has not been used in this field, the success criteria for determining the needs were developed, and a general decision-making structure was developed about which technique/technique could meet the needs at which level and to what extent. At the same time, it is ensured that the need classes are used as stopping rules in determining the needs. When the techniques are examined; It can be said that the flow chart technique is very effective in determining processlevel needs and determines all the needs at this level, it is low in terms of purpose-level needs, normal in terms of task-level needs, and very low in terms of information-level needs. Associative knowledge map technique; While goal-level requirements are normal, they have very low identifying efficiency in terms of process, task, and information-level requirements. As a result, it is a system that determines how the proposed model in the studies of determining the system needs can meet the needs at the defined level (purpose, process, task, and informatics) of the technical/technical combinations described in the model. The model is straightforward to use and flexible to be applied to any environment.

At the same time, obtained with the model, the numerical value and linguistic variables of the need determination rates in case the need classes are used as stopping rules, the relationship between the techniques' needs determination efficiency measures, and the techniques were used as stopping rules evaluated. In addition, the "need identification effectiveness measure of the techniques" $\left(t_{e}\right)$ values and the numerical value/linguistic variables of the technique/technical combinations in training set in terms of determining the needs were evaluated by means of the t-test, and it was examined whether there was a significant difference between them. It is possible to say that there is no statistically significant difference at the $5 \%$ significance level (95\% confidence interval) between the class range and values. As a result, ROC and RULES-3 algorithms give similar results based on the need-determination efficiency success criterion of the techniques. In addition, the correlation analysis shows that the combination, which is determined as the most effective and determines the needs in the entire need set (all 40 requirements), has the most efficient value in terms of requirements determination efficiency.

If the Associative information map, Decision map, and Similarity diagram (T2-T3-T5) techniques are used in the system requirements determination studies, all the needs are met. This combination obeys rule 12 produced by RULES-3. This combination also determines all the requirements as defined in the ROC algorithm. In conclusion; Associative information map (T2) to identify goal-level needs, Flowchart, Decision map and Scenario (T1, T3, and T4) to identify processlevel needs, Decision map (T3) to identify task-level needs, and Similarity diagram (T5) to identify information-level needs technique can be said to be the most effective technique.

\section{Results}

When the applied system requirements model (SRM) is evaluated, all the needs are met if the Associative information map, Decision map, and Similarity diagram (T2-T3-T5) techniques are used. This combination obeys rule 12 produced by RULES -3 . This combination also determines all the requirements as defined in the ROC algorithm. Also; Associative information map (T2) to identify goal-level needs, Flowchart, Decision map and Scenario (T1, T3, and T4) to identify process-level needs, Decision map (T3) to identify task-level needs, and Similarity diagram (T5) to identify information-level needs technique can be said to be the most effective technique.

Table 10 below shows the 12 rules produced by RULES-3 for the purchase request. These 12 rules cover all 31 examples given in the training set above. With the help of this created training set and the rules generated from it, inference-based modeling/inductive learning, a general approach was adopted starting from a specific example, and a model was developed that could give beneficial results in other systems. As a result, the model was generalized.

Information; This study was derived from a $\mathrm{Ph}$. $\mathrm{D}$. thesis titled An Inductive-ROC Based Model in Requirement Determination.

\section{References}

Aksoy, M. S., (2005). Dynamic System Modelling Using Rules3 Induction Algorithm. Mathematical and Computational Applications, Vol. 10, No. 1, pp. 121-132.

Aksoy, M. S., (2005). Pruning Decision Trees Using Rules3 Inductive Learning Algorithm. Mathematical and Computational Applications. Vol. 10, No. 1, pp. 113-120

Alvarez, R., (2002). Discourse Analysis of Requirements and Knowledge Elicitation Interviews. Proceedings of the 35th Hawaii International Conference on System Sciences, IEEE Computer Society.

Bano, M., Zowghi, D., Ferrari, A., Spoletini \& P., Donati, B. (2018). Learning from Mistakes: An Empirical Study of Elicitation Interviews performed by Novices. International Requirements Engineering Conference - Banff, Alberta Canada.

Browne, G.J., \& Pitts, M.G. (2004). Stopping Rule Use During Information Search in Design Problems. Organizational Behavior and Human Decision Processes. 95, 208-224. 
Browne, G.J., \& Rogich, M.B. (2001). An empirical investigation of user requirements elicitation: comparing the effectiveness of prompting techniques. Journal of Management Information Systems. Vol. 17 No 4, pp. 223-249.

Browne, G.J., Ramesh, V., "Improving information requirements determination: a cognitive perspective", Information \& Management, 39 (2002), pp. 625-645

Byrd, T. A., Cossick, K. L., \& Zmud, R. W. (1992). A Synthesis of Research on Requirements Analysis and Knowledge Acquisition Techniques. MIS Quarterly. 16 (1), 117-138.

Carrizo, D., Dieste, O., \& Juristo, N. Systematizing requirements elicitation technique selection. (Access date; 30.06.2021), http://oa.upm.es/37447/1/INVE_MEM_2014_1954 80-3.pdf

Carrizo, D., Ortiz, C., \& Aguirre, L. (2016) What do researchers mean by "the right requirements elicitation techniques". Revista chilena de ingeniería. vol. $24 \mathrm{~N}^{\circ}$ 2, pp. 263-273.

Cascio, W. F., \& Montealegre, R. (2016). How technology is changing work and organizations. Annual Review of Organizational Psychology and Organizational Behavior. (3), 349-375.

Darke, P., \& Shanks, G. (1997). User viewpoint modelling: understanding and representing user viewpoints during requirements definition. Information Systems Journal. Vol. 7, pp. 213-239.

Davidson, E.J. (2002). Technology frames and framing: a socio-cognitive investigation of requirements Determination. MIS Q. 26 (4) 329-358.

Davis, G. B. (1982). Strategies for Information Requirements Determination. IBM Systems Journal. 21(1), 4-30.

Duggan, E.W. (2003). Generating systems requirements with facilitated group techniques. Hum. Comput. Interact. 18 (4), 373-395.

Freeman, L., A. (2004). The Effects Of Concept Maps on Requirements Elicitation And System Models During Information Systems Development. Concept Maps: Theory, Methodology, Technology Proc. of the First Int. Conference on Concept Mapping. Pamplona, Spain.

Guinan, P. J, Cooprider, J. G., \& Faraj, S. (1998). Enabling Software Development Team Performance During Requirements Definition: A Behavioral Versus Technical Approach. Information Systems Research. Vol. 9, No. 2.

Hadar, I., Soffer, P., \& Kenzi, K. (2012). The role of domain knowledge in requirements elicitation via interviews: an exploratory study. Springer-Verlag London Limited.

Hanish, J., Thanasankit, T., \& Corbitt, B. (2001). Exploring the cultural and social impacts on the requirements engineering processes - highlighting some problems challenging virtual team relationships with clients. Journal of Systems and Information Technology. Vol. 5, No.2, pp. 1-19.

Hickey, A. M., \& Davis, A., M. (2004). A Unified Model of Requirements Elicitation. Journal of Management Information Systems. Vol. 20, No. 4, pp. 65-84.

Janz, B.D., Frolick, M.N., \& Wetherbe, J.C. Human Perception: A Challenge to Organizational Process Optimization. (Access date; 30.06.2021) https://citeseerx.ist.psu.edu/viewdoc/download?doi $=10.1 .1 .563 .6642 \&$ rep=rep1\&type=pdf

King, J.R., (1980). Machine Component Grouping Formation in Group Technology. International Journal of Management Science. Vol. 8(2), pp. 193199.

Laudon K. C., \& Laudon J. P. (2014). Management Information Systems Managing the Digital Firm, Thirteenth Edition, Pearson Education Limited, https://repository.dinus.ac.id/docs/ajar/Kenneth_C. Laudon,Jane_P_.Laudon__Management_Information_Sysrem_13th_Edition_ .pdf (Access date;; 6.06.2021)

Lazar, J., Hanst, E., Buschwalter, J., \% Preece, J. (2000). Collecting User Requirements in a Virtual Population, WebNet Journal: Internet Technologies. Applications and Issues. Vol. 2 No. 4, pp. 20-27.

Över Özçelik, T., \& Torkul, O. (2019). Bilişim Sistemi Geliştirmede İhtiyaç Belirleme. Iksad Publications Ankara / Turkey, ISBN: 978-625-7954-15-0.

Över, T., (2006). İhtiyaç Belirlemede Endüktif-Roc Temelli Bir Model. Doktora Tezi, Sakarya Üniversitesi Fen Bilimleri Enstitüsü.

Pitts, M. G. \& Browne, G. J. (2004). Stopping Behavior of Systems Analysts During Information Requirements Elicitation. Journal of Management Information Systems. 21:1, 203-226

Shams, F., Ammar, H., \& Bhutta, M. (2019). Selection of Software Requirements Elicitation Techniques- A Systematic Review. Journal of Multidisciplinary Approaches in Science. 1, Issue 1, 8-17.

Sommerville, I., Sawyer, P., \& Viller, S. (1998). Viewpoints for Requirements Elicitation: a practical approach. Third International Conference on Requirements Engineering. IEEE Computer Society Press, pp. 74-81.

Sutcliffe, A. (2003). Scenario-based requirements engineering. Paper presented at: Proceedings 11th IEEE international requirements engineering conference. IEEE, pp. 320-329.

Tiwari, S. \& Rathore, S. S. (2017). A Methodology for the Selection of Requirement Elicitation Techniques. arXivPrepr. arXiv1709.08481.

Vessey, I. \& Conger, S. (1993). Learning to Specify Information Requirements: The Relationship 
Between Application and Methodology". Journal of Management Information Systems, 10 (2), 177-201.

Vessey, I. \& Conger, S. (1994). Requirements specification: learning object, process, and data methodologies. Communications of the ACM. 37 (5), 102-113.

Wahbeh, A., Sarnikar, S., \& El-Gayar, O. (2019). A socio-technical-based process for questionnaire development in requirements elicitation via interviews. Requirements Engineering. 1-21, (Access date; 30.06.2021), https://scholar.dsu.edu/bispapers/136/

Watson, H. J. \& Frolick, M. N. (1993). "Determining Information Requirements for an EIS". MIS Quarterly. 17(3), 255-269.

Wetherbe, J.C. (1991). Executive Information Requirements: Getting It Right. MIS Quarterly. Vol. 15, pp. 51-65.

Whitten, J.L. \& Bentley, L.D.. (2007). Systems Analysis and Design Methods. McGraw-Hill/Irwin, 7th Edition. 